\title{
Factors Motivating Customers' SNS Brand Page Behaviors: A Comparison Between China and Korea
}

\author{
Mengmeng Song \\ Hainan University \\ smmlgl@msn.com \\ Nan Wang* \\ Eastern Illinois University \\ nwang@eiu.edu \\ Xianfeng Zhang \\ Hainan Normal University \\ 35203286@qq.com \\ Lin Qiao \\ Hainan University \\ 776360135@qq.com
}

\begin{abstract}
The wide use of Social Network Site (SNS) brand pages by companies has renovated brand strategies in the new era. This study is to provide meaningful implications regarding companies' effective use of SNS brand pages and help global companies with their development of brand strategies. Using survey, this study investigates motivating factors (functional benefits, hedonic benefits, economic benefits, intrinsic benefits, and brand reputation) influencing SNS brand page users' participation and commitment and the subsequent impact on purchase intention. Potential cultural differences between Chinese and Korean users are also examined along Hofstede's culture framework. The results show that prior motivating factors found in traditional online brand communities largely hold in the context of SNS brand page in both countries, but there are differences in the significance and importance of motivating factors between the two countries. Implications and contributions are discussed.
\end{abstract}

Keywords: Social Network Sites, Brand Page, Brand Community, Motivating Factor, Culture, Participation, Commitment, Purchase Intention

Citation: Song, M., Wang, N., Zhang, X. and Qiao, L. (2017). " Factors Motivating Customers' SNS Brand Page Behaviors: A Comparison Between China and Korea," Pacific Asia Journal of the Association for Information Systems, 9(4), pp. 25-50. 


\section{Introduction}

The prevalence of the Internet has enabled individuals from all over the world to form communities based on common interests without geographic restrictions. An online brand community, defined as "a specialized, non-geographically bound community, based on a structured set of social relations among admirers of a brand" (Muniz and O' Guinn, 2001), is typically formed based on attachment to a brand or to its product/ service. Common interests, socio-economic similarities, and shared consciousness, rituals and traditions, and a sense of moral responsibility can be the essential foundation of brand communities. This kind of online brand community is referred to as traditional online community.

A special form of online brand community is Social Network Site (SNS) brand page (also known as brand page or fan page). SNS brand page, which is organized around a single brand, product/service, or company, represents an emerging form of Information and Communications Technology (ICT) that provides constant connectivity among users worldwide. SNS brand page is widely used nowadays. Take brand pages on Facebook as an example. About $97 \%$ of the top brand have brand page on Facebook (Simply Measured, 2017) and $71 \%$ of Facebook users have purchased products/services of brand pages (Yang et al., 2016). SNS brand page can help direct messages and posts to subscribed users, promote and lead discussions about a brand (or its product/ service), arouse individual awareness, and contribute to tight social networks among subscribed users. Companies can easily deliver a variety of contents related to their brands and timely communicate with potential or existing customers (Boyd and Ellison, 2007). The wide spread use of SNS brand page by companies has renovated their brand management strategies in the new era.

SNS brand pages, however, differ from traditional online brand communities in two major aspects. First, unlike a traditional online brand community that is largely userdriven, a SNS brand page is mainly company-driven and is used as an explicit channel for brand-related communication and interaction between users and the brand. Second, while a traditional online brand community is based on pure brandlikeness, a SNS brand page may not be so (Boyd and Ellison, 2007; Jahn and Kunz, 2012). Members of traditional online brand communities typically have strong attachment or commitment to the brand (or its product/service), are willing to share their values, and bear a sense of moral responsibility (Boyd and Ellison, 2007; Jahn and Kunz, 2012). In contrast, users of SNS brand pages may not "like" the brand (or its product/service). Instead, they become users of SNS brand pages because they want to control SNS brand pages by producing and distributing online content related to the brand (or its product/service), to receive discounts or freebies, to be connected to SNS "friends" who might neither be "fans" of the brand (or its product/ service), or to signal their self-identity (Boyd and Ellison, 2007).

Extant research has studied motivating factors (or motivators) for members' participation and commitment in traditional online brand communities (Fornell and Larcker,1981; Jackson and Wang, 2013; Li et al., 2006), and the influence of participation/commitment on, for example, purchase intention (Borle et al., 2012; Garbarino and Johnson, 1999; Vasalou et al., 2010). However, there is still a lack of systematic investigation regarding users' participation and commitment in the context of SNS brand page (Kang et al., 2014). Due to the differences between SNS brand pages and traditional online communities discussed before, we wonder whether the motivators-participation/commitment-

purchase intention relationship examined in current literature about traditional online community still holds in the context of SNS brand page.

Moreover, we are interested in potential cultural differences in the motivators- 
participation/commitment-purchase intention relationship in the context of SNS brand page. In this study, we choose to focus on potential differences between China and Korea for three reasons: first, both countries have very active users of SNS brand page; second, both countries, though started from the bottom of the world GDP list, climbed up to the top place among Organization for Economic Co-operation and Development (OECD) countries (Kim, 2016) and are now major market for global companies; third, although China and Korea are similar in some ways (e.g., they score similarly on Hofstede's individualism-collectivism dimension) (e.g., Hofstede, 1983), the two countries also differ in other aspects (e.g., uncertainty avoidance) that are likely to lead to differences in the motivator-participation/ commitment-purchase intention relationship (e.g., Dawar et al., 1996).

Our current understanding about crosscultural differences in the motivatorsparticipation/commitment-purchase intention relationship in the context of SNS brand page is quite limited and fragmented. In this study, we seek to understand potential cultural differences between China and Korea in a systematic way via applying Hofstede's culture framework, a widely used framework for understanding cross-cultural issues that has not been adequately applied in the context of SNS brand page (e.g., Sheldon et al., 2017). Specifically, we discuss how China and Korea are different according to Hofstede's culture dimensions and later interpret cross-cultural difference findings along those dimensions. Understanding China-Korea differences using Hofstede's culture framework may also increase the applicability of our research findings: even though this study only looks at China and Korea, our findings may apply to other cultures that score similarly with China/Korea along Hofstede's culture dimensions.

Understanding the motivators-participation/ commitment-purchase intention relationship in the context of SNS brand page as well as potential cultural differences in it is of practical values. As an effective tool to improve brand image, to connect with potential consumers and to strengthen relationships with existing consumers, SNS brand pages are widely utilized by brands. Nowadays, millions of users are connected on SNS brand pages, and their commitment and participation are crucial for the success of SNS brand pages: active members that participate frequently in SNS brand page activities create highly interactive environment where they provide information about, for example, service encounters, which consequently influences purchase (Mahrous and Abdelmaaboud, 2017); commitment, which may increase users' psychological dependence towards the brand, could also influence purchase (Han, 2016). As a result, industry practitioners are paying more attention to operating SNS brand pages. However, not all SNS brand pages are successful at attracting (active and committed) users and at influencing their purchases. For example, brands with millions of fans on Facebook have seen organic reach (i.e., how many people you can reach for free by posting to your page) fall below 2\% (Rosenthal and Brito, 2017).

Moreover, a certain SNS brand page strategy that works well in one culture may not be as effective in another. For instance, while brand pages on Facebook prefer to use navigation and video communications to engage users, those on Renren, a popular SNS platform in China, reply more on human-to-human interactivity by constantly responding to posts (Men and Tsai, 2012). In fact, cross-cultural research on consumer behaviors consistently recommended that different strategies should be implemented in different cultures (e.g., Henten et al., 2003; Lee et al., 2002).

This study may provide practical implications regarding how to motivate individuals to participate in SNS brand page, to become committed and eventually to influence their purchase of related products/ services. The investigation of cultural differences between China and Korea provides additional country-specific 
understandings that are helpful for global companies with tailoring their SNS brand page strategies for different cultures.

The remaining of the paper are organized as follows. We first review related literature, leading up to our hypotheses. Then we discuss data collection and analysis. After that, we discuss research findings, implications, limitations and future research directions.

\section{Literature Review and Hypothesis Development}

In this section, we start with discussing the relationship between participation/ commitment and purchase intention in SNS brand pages. We then discuss motivating factors affecting participation and commitment. In the end, we discuss potential cultural differences between China and Korea for the examined relationship. An illustration of our research model is provided in Figure 1.

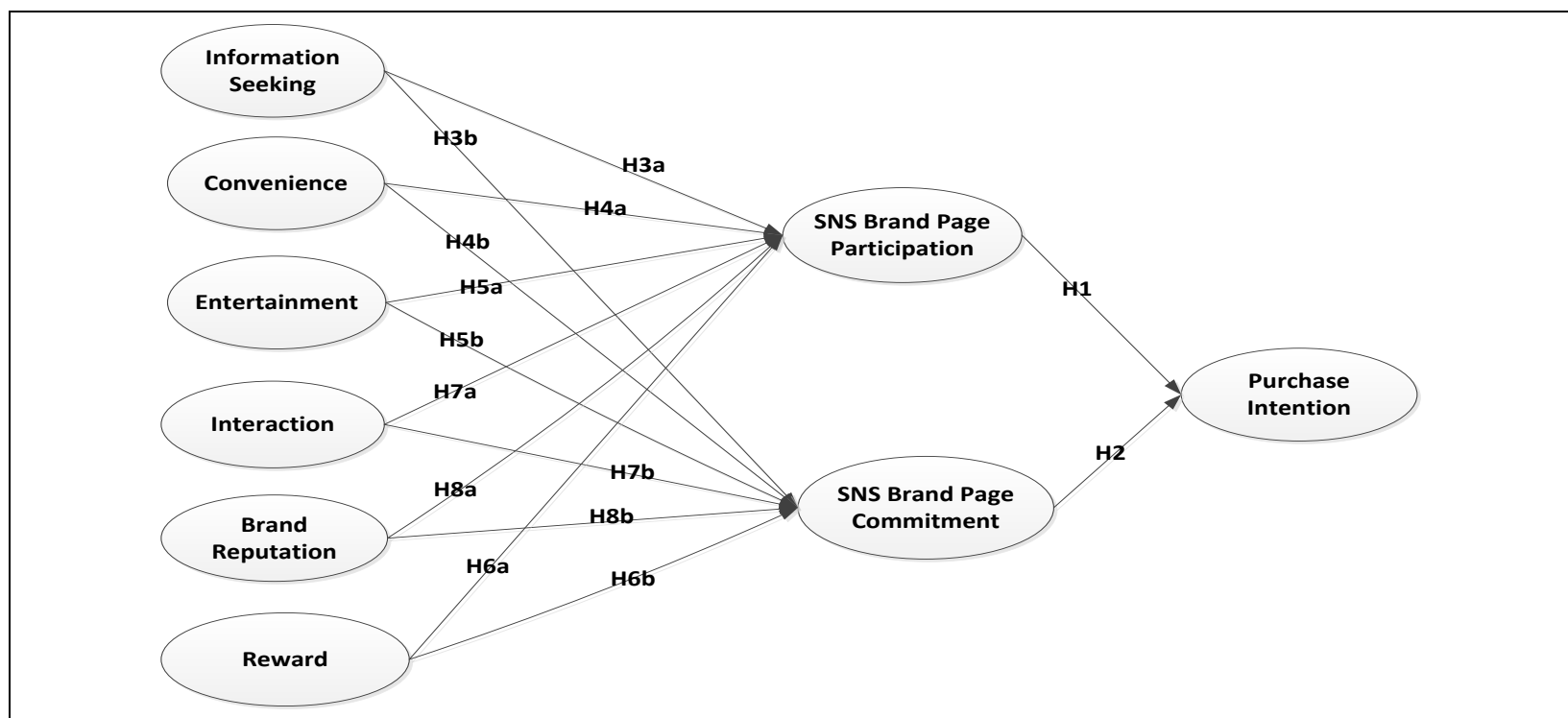

Figure 1 - Research Model

\section{SNS Brand Page Participation, Commitment and Purchase Intention}

Participation in SNS brand page refers to engaging in activities (e.g., creating messages, disseminating information) and providing emotional support to others (Borle et al., 2012). Active participators of SNS brand page typically show high levels of interest-though not necessarily likeness-in the brand (or its product/service), and constantly update their knowledge through interactions with the brand and communications with other users. Frequent participations in SNS brand page can enhance individuals' brand knowledge
(Morgan and Hunt, 1994) and strengthen individual-brand bond.

Commitment in SNS brand page reflects a strong and positive psychological attachment to a brand (or its product/service) (Beatty and Kahle, 1988). This attachment may be generated from prior internal emotional involvement with the brand (Zaichkowsky, 1985) or long-term relationship with the brand (Butler and Cantrell, 1994).

Participation and commitment in SNS brand page help build individual-brand relationships, which consequently influence other downstream behaviors and attitudes towards the brand or its product/service 
(Flavián and Guinalíu, 2006; Kassim and Abdullah, 2010). Research on traditional online brand communities found that participation has significant influence on purchase behaviors (Borle et al., 2012; Kassim and Abdullah, 2010), and commitment has a significant influence on individuals' continuous usage (Lee et al., 2008) and brand attachment such as trust and loyalty (Zeithaml et al., 1996). Focusing on purchase intention, we suspect

H1. Participation in SNS brand page is positively associated with purchase intention.

H2. Commitment in SNS brand page is positively associated with purchase intention.

\section{Uses and Gratifications Theory and Motivators for SNS Brand Page Participation and Commitment}

To understand motivators for participation and commitment in SNS brand page, we turn to uses and gratifications theory (UGT). According to UGT, individuals, who are goal-oriented (Rubin,1993), evaluate benefits or gratifications and generate behaviors when they believe that their needs could be satisfied (Lee and $\mathrm{Ma}$, 2012). UGT has been used as a framework to understand how and why people actively seek out specific types of media (Hagit and Efrat, 2017; Severin et al., 1997). Although UGT was originally applied to examine traditional media (e.g., newspaper, television) (Katz et al., 1973; Kippax and Murray, 1980), recent studies have applied UGT to new media (e.g., social media) (Flanagin, 2005; Leung, 2001).

In the context of traditional online brand community, UGT argues that individuals actively turn to online brand communities to satisfy their needs; if individuals' needs could be fulfilled, gratifications or satisfactions will be generated, which may then lead to active participation and great commitment in online brand communities (Venkatesh and Brown, 2001; Sangwan, 2005; Guo et al., 2010; Wang, 2014).
Existing literature on motivators affecting individuals' participation/commitment in traditional online communities suggest that there are five major groups of motivators, namely functional benefits, hedonic benefits, economic benefits, intrinsic benefits and brand reputation. We suspect the five major groups of motivators still apply (at least to some extent) in the context of SNS brand page. Generally, SNS users expect entertaining content, some remuneration, good responses, interaction, useful information and so on in return for engaging in SNS brand page activities such as liking, commenting and sharing activities and ideas towards brand posts (Kujur and Singh, 2017; Vivek, 2009; Vidya et al.,2015). In the following, we provide detailed discussion for each of the motivators.

\section{Functional Benefits}

Functional benefits refer to concrete outcomes that individuals can receive from using the media (e.g., SNS brand page). Functional benefits include two aspects associated with the information (or system) quality provided by the media, i.e., information seeking and convenience (i.e., easy access of anytime-anywhere benefits deriving from the ease of use in either computer-based websites or applications on small devices). Research on traditional online communities suggests that the motivations to seek information (Fornell and Larcker, 1981) and convenience (Nambisan and Baron, 2009) lead to active participation and high commitment in online brand communities.

In the context of SNS brand page, the two functional benefits (i.e., information seeking and convenience) are likely to have similar impacts on participation and commitment (Dholakia et al., 2004; Raacke and BondsRaacke, 2008; Lin and Lu, 2011; Muntinga et al., 2011; Li et al., 2006). When SNS brand page users immerse themselves into the "information warehouse", they can find timely answers for their inquiries and spread information to other users without time or distance constraints. If a brand post 
contains useful information about the brand (or its product or service), then individuals' motivations to participate or consume the content are met (Vriesa et al.,2012). Besides, information dissemination via SNS brand pages is easy and convenient, which further facilitate smooth interactions among users (Ko et al., 2005; Ul Haq, 2012). Therefore, the gratification of the two functional benefits is expected to exert a significant and positive impact on users' participation and commitment in SNS brand page. Hence, we propose

H3a. Information seeking is positively associated with SNS brand page participation.

$\mathrm{H} 3 \mathrm{~b}$. Information seeking is positively associated with SNS brand page commitment.

$\mathrm{H} 4 \mathrm{a}$. Convenience is positively associated with SNS brand page participation.

H4b. Convenience is positively associated with SNS brand page commitment.

\section{Hedonic Benefits}

Hedonic benefits (i.e. entertainment) refer to the various pleasures that individuals may feel when using the media (Dholakia et al., 2004; Li et al., 2006; Sheldon, 2008) and the utility of such feelings or affective states (e.g., enjoyment) (Vasalou et al., 2010). The intent to seek entertainment motivates individuals to spend their leisure time on the diverse activities (e.g. games, contests, polls) available in SNS brand pages, which may arouse or elicit positive emotions and passion (Armstrong and Hagel, 1995) that consequently further motivate them to more extensively use SNS brand pages. Also, SNS brand pages can provide individuals with opportunities to gather and explore new things that they seldom experience offline. For instance, Facebook users can be entertained through various ways such as surfing on a friend's page or learning what their friends are doing by reading through newsfeed (SINA, 2013). The entertained users are likely to experience greater satisfaction, which will further motivate them to participate in or commit to SNS brand pages (Raju et al., 2009). Thus, we argue

H5a. Entertainment is positively associated with SNS brand page participation.

H5b. Entertainment is positively associated with SNS brand page commitment.

\section{Economic Benefits}

Economic benefits refer to bonuses or compensations that individuals receive. For SNS brand pages, the term reward is often used to describe the economic incentives individuals perceived through a variety of compensation activities (Mengze and Andrea, 2014). Research on traditional online brand communities found that bonuses such as gift certificates ( $\mathrm{Ha}$ and Perks, 2005) and special promotions and coupons (Treadaway and Smith, 2012) are likely to strengthen individual-brand relationship. The greater the economic benefits are, the greater customers' satisfaction and loyalty will be (Sung et al., 2010), and the greater the participation and commitment (Garbarino and Johnson, 1999; Sung et al., 2010). We suspect such relationship to hold in the context of SNS brand page. Hence,

H6a. Reward is positively associated with SNS brand page participation.

H6b. Reward is positively associated with SNS brand page commitment.

\section{Intrinsic Benefits}

Intrinsic benefits depict the internal psychological outcomes like self-esteem benefits and social benefits that one can perceive in using the media. Interaction is essential for individuals' intrinsic benefits and can encourage participation and commitment (Armstrong and Hagel, 1995). Brand page membership can be used by individuals to show peers their social presence and to signal their self-identity; it can also be used to share with others interesting encounters and joy that may rapidly spread to all users (Muniz and O' 
Guinn, 2001). If individuals receive quick responses from and can closely connect with other users, the feeling of being recognized and paid attention to will lead to a sense of self-concept and self-esteem (Yen et al., 2011), which may lead to active participation and great commitment (Bagozzi and Dholakia, 2002). For example, Ruiz-Mafe et al. (2014) found that interactions at Facebook brand page play an essential role in improving user attitude and loyalty. Thus,

$\mathrm{H} 7 \mathrm{a}$. Interaction is positively associated with SNS brand page participation.

H7b. Interaction is positively associated with SNS brand page commitment.

\section{Brand Reputation}

Brand reputation is another motivator for participation and commitment. Individuals tend to search for a reliable and responsible brand that may help reduce innate risks associated with the products and services (Delgado-Ballester et al., 2003). SNS brand pages offer individuals a new way of knowing the brand, understanding its product/service, contacting the company, and communicating with peer customers or users. If individuals perceive a brand (or its product/ service, salesperson, the company image) as trustworthy, they may actively participate in the SNS brand page and develop a sense of commitment and affection (Beatty and Kahle, 1988; Heckhausen and Heckhausen, 2008). Therefore, we propose

$\mathrm{H} 8 \mathrm{a}$. Brand reputation is positively associated with SNS brand page participation.

H8b. Brand reputation is positively associated with SNS brand page commitment.

\section{Cultural Differences in SNS Brand Page Participation and Commitment}

It is well-recognized that culture influences individuals' behaviors and attitudes (De Mooij, 2004; De Mooij, 2010; Tse et al.,
1989), including participation and commitment in traditional online brand communities (Ahn et al., 2010; Van Doorn et al., 2010). The literature on SNS users' attitudes and behaviors has recognized the existence of cultural differences. For example, Kim et al. (2011) examined US and Korean college students' use of SNS and found significant differences in the importance (i.e., weight) of major motivators for (e.g., Korean users emphasize more on obtaining social support from current relationships while US users emphasize more on seeking entertainment) and in the patterns of using SNS (e.g., US users have a much larger SNS network). In a study about Facebook users in five countries (i.e., United States, United Kingdom, Italy, France, Greece), Vasalou et al. (2010) also found significant cultural differences in users' motivation for and commitment in using Facebook.

The most comprehensive and robust framework for understanding cultural differences (see Soares et al., 2007 for a review), despite the criticism received, is Hofstede's culture framework (Hofstede, 1983). Hofstede's framework was initially developed to understand human resource management. Over the years, the framework has been used in various disciplines (e.g., communication, psychology, marketing, and management) (Sondergaard, 1994; Steenkamp, 2001) to understand phenomena such as consumer behaviors (Milner et al., 1993; Sondergaard, 1994; Dawar et al., 1996).

According to Hofstede's culture framework, there are five dimensions, namely individualism (i.e., the degree of interdependence among members of a culture), power distance (i.e., the extent to which less powerful members of a culture expect and accept that power is distributed unequally), uncertainty avoidance (i.e., the extent to which members of a culture feel threatened by ambiguous or unknown situations), masculinity (i.e., the extent to which members of a culture prefer achievement and success over relationships, 
caring for others and quality of life), and long-term orientation (i.e., the extent to which members of a culture focus on the future and value persistence and perseverance). These culture dimensions have been found to affect behaviors and attitudes related to motivators, participation, commitment and purchase intention. For example, research found that the individualism-collectivism dimension explained cultural differences in individuals' use of SNS (e.g., frequency of usage) (e.g., Jackson and Wang, 2013).

Among the five dimensions discussed in Hofstede's framework, China and Korea differ in two aspects, i.e., uncertainty avoidance (China scores low on uncertainty avoidance while Korea is one of the most uncertainty avoiding countries) and masculinity (China is a masculine society while Korea is considered a feminine one). Those differences may lead to cultural differences in the motivatorsparticipation/commitment-purchase intention relationship we seek to understand. For example, consumer behavior research suggested that uncertainty avoidance explains cross-cultural differences in advertising appeals such as convenience, enjoyment and effectiveness (Soares et al., 2007), which are closely related to some of the motivators examined in this study such as convenience, entertainment and information seeking. Uncertainty avoidance is also found to affect individuals' information search behaviors (Dawar et al., 1996), which are again related to the phenomenon examined in our study.

Moreover, although some cross-cultural research did not use Hofstede's culture framework, their findings might well be explained via applying Hofstede's ideas. For example, research on website characteristics affecting flow and satisfaction suggested that Korean and Chinese users differ in their emphases on aesthetics and convenience of website design (Fan, Lim and Kim, 2013), which might be due to the differences in the masculinity and/or uncertainty avoidance of the two cultures (e.g., Albers-Miller and Gelb, 1996; Soares et al., 2007).

In summary, considering the differences in the uncertainty avoidance and masculinity dimensions between China and Korea and how the two dimensions have been found to affect attitudes and behaviors related to motivation, participation/commitment and purchase intention, we suspect that cultural differences may exist for our hypotheses discussed above.

H9. The motivators-participation/ commitment-purchase intention relationships are different between Chinese and Korean SNS brand page users.

\section{Method}

\section{Data Collection and Construct Measurement}

We collected data using online survey with the assistance of two leading commercial market research institutions, one in China and one in Korea. Two versions of the survey (one in Chinese and one in Korean) were prepared and translated separately by two bi-lingual graduate students to ensure that no discrepancies existed. Approximately 500 copies of surveys were distributed in each country. 384 valid responses were collected from Korea and 407 were collected from China. To be included in this study, participants must be active users of certain SNS brand pages (e.g., Coke-Cola, BMW, Starbucks, McDonald, Samsung, and Lenovo)-we asked respondents whether they are active users of SNS brand pages at the beginning of the survey. If the answer is negative, then the survey will not start. Demographic details (collected at the end of the survey) of the sample are provided in Table 1. Constructs were measured using existing scales (5-point Likert) adopted from the literature (Appendix A). Results of exploratory factor analysis (Appendixes B and $C$ ) suggest 9 factors. 


\begin{tabular}{l} 
Table 1 - Demographics of Respondents \\
\hline
\end{tabular}

\section{Common Method Bias}

As data is self-reported and collected from a single source, a potential problem is common method bias (CMB). We addressed this issue following suggestions of (Podsakoff et al., 2003). First, respondents were assured of anonymity and confidentiality of their responses to minimize concerns about social desirability. Second, measurement items of the same construct were put in different places on the survey to reduce respondents' perception of direct connections among these items. Finally, Harman's one-factor test was used, and results revealed more than one factor with eigenvalue value above 1 , with the first factor accounting for $37.83 \%$ of the total variance. Hence, CMB is unlikely to be a serious concern.

\section{Reliability and Validity Test}

A confirmative factor analysis (Table 2) with maximum likelihood estimation in AMOS 21.0 was conducted to assess construct reliability and validity of the measurement model. The reliability was tested by checking the internal consistency (i.e. Cronbach's alpha). Cronbach's alpha values for all constructs are greater than 0.7. In addition, composite reliabilities are found to be above 0.8 for all constructs. Both signal satisfactory construct reliability. Construct validity consists of convergent validity and discriminant validity. In general, convergent validity can be claimed when t-values are 2.0 or above, standardized factor loadings are 0.5 or above, or averaged variances expected (AVEs) are 0.5 or above (Bagozzi and $\mathrm{Yi}$, 1988). Discriminant validity is confirmed when all exceed the minimum level of 0.5(Dodds et al., 1991; Jin et al., 2010). All constructs demonstrate adequate validity.

\section{Hypothesis Testing}

The effect and statistical significance of parameters in SEM were tested using the bootstrapping procedure in AMOS 21.0. The test results (Table 3) show good fitness for the structural model using both samples.

Results for China and Korea are presented in Figure 2 and Figure 3. Most of the proposed hypotheses are supported with a few exceptions. $\mathrm{H} 3 \mathrm{a}$ and $\mathrm{H} 3 \mathrm{~b}$ are supported for Korean sample, but not for Chinese sample, which indicates that information seeking is not positively associated with either participation or commitment for Chinese respondents. $\mathrm{H} 4 \mathrm{a}$ and $\mathrm{H} 4 \mathrm{~b}$ are supported for Chinese sample but not for Korean sample, which means that convenience does not have a significant influence on Korean respondents' participation/commitment in SNS brand page. In addition, no positive association is found between commitment and purchase intention (H2) among Korean respondents. 
Pacific Asia Journal of the Association for Information Systems, Vol. 9, Iss. 4 [2018], Art. 3

Factors Motivating Customers' SNS Brand Page Behaviors / Song et al.

Table 2 - Factor Loadings, Cronbach's Alpha, Averaged Variances Expected, and Composite Reliabilities

\begin{tabular}{|c|c|c|c|c|c|c|c|c|}
\hline \multirow{2}{*}{ Constructs Items } & \multicolumn{2}{|c|}{ Factor loading } & \multicolumn{2}{|c|}{ Cronbach's Alpha } & \multicolumn{2}{|c|}{ AVE } & \multicolumn{2}{|c|}{ CR } \\
\hline & China & Korea & China & Korea & China & Korea & China & Korea \\
\hline $\begin{array}{c}\text { Information seeking } \\
\text { Item } 1 \\
\text { Item } 2 \\
\text { Item } 3 \\
\text { Item } 4\end{array}$ & $\begin{array}{l}.833 \\
.803 \\
.843 \\
.843\end{array}$ & $\begin{array}{l}.739 \\
.555 \\
.773 \\
.724\end{array}$ & .898 & .792 & .70 & .50 & .90 & .80 \\
\hline $\begin{array}{c}\text { Convenience } \\
\text { Item } 1 \\
\text { Item } 2 \\
\text { Item } 3\end{array}$ & $\begin{array}{l}.874 \\
.808 \\
.730\end{array}$ & $\begin{array}{l}.822 \\
.701 \\
.596\end{array}$ & .839 & .741 & .65 & .51 & .96 & .93 \\
\hline $\begin{array}{c}\text { Entertainment } \\
\text { Item } 1 \\
\text { Item } 2 \\
\text { Item } 3\end{array}$ & $\begin{array}{l}.847 \\
.885 \\
.868\end{array}$ & $\begin{array}{l}.741 \\
.794 \\
.757\end{array}$ & .900 & .808 & .75 & .59 & .90 & .81 \\
\hline $\begin{array}{l}\text { Interaction } \\
\text { Item } 1 \\
\text { Item } 2 \\
\text { Item } 3 \\
\text { Item } 4\end{array}$ & $\begin{array}{l}.840 \\
.860 \\
.826 \\
.805\end{array}$ & $\begin{array}{l}.576 \\
.569 \\
.809 \\
.824\end{array}$ & .901 & .800 & .70 & .49 & .90 & .80 \\
\hline $\begin{array}{c}\text { Brand reputation } \\
\text { Item } 1 \\
\text { Item } 2 \\
\text { Item } 3\end{array}$ & $\begin{array}{l}.842 \\
.848 \\
.827\end{array}$ & $\begin{array}{l}.710 \\
.875 \\
.705\end{array}$ & .882 & .807 & .71 & .59 & .88 & .81 \\
\hline $\begin{array}{l}\text { Reward } \\
\text { Item } 1 \\
\text { Item } 2 \\
\text { Item } 3\end{array}$ & $\begin{array}{l}.844 \\
.880 \\
.855\end{array}$ & $\begin{array}{l}.857 \\
.776 \\
.618\end{array}$ & .894 & .793 & .74 & .58 & .90 & .80 \\
\hline $\begin{array}{l}\text { Participation } \\
\text { Item } 1 \\
\text { Item } 2 \\
\text { Item } 3\end{array}$ & $\begin{array}{l}.824 \\
.807 \\
.864\end{array}$ & $\begin{array}{l}.677 \\
.659 \\
.791\end{array}$ & .871 & .747 & .70 & .52 & .87 & .76 \\
\hline $\begin{array}{l}\text { Commitment } \\
\text { Item } 1 \\
\text { Item } 2 \\
\text { Item 3 } \\
\text { Item } 4\end{array}$ & $\begin{array}{l}.811 \\
.715 \\
.837 \\
.812\end{array}$ & $\begin{array}{l}.778 \\
.676 \\
.817 \\
.771\end{array}$ & .879 & .845 & .88 & .65 & .88 & .88 \\
\hline $\begin{array}{c}\text { Purchase intention } \\
\text { Item } 1 \\
\text { Item } 2 \\
\text { Item } 3\end{array}$ & $\begin{array}{l}.845 \\
.875 \\
.896\end{array}$ & $\begin{array}{l}.812 \\
.872 \\
.897\end{array}$ & .905 & .895 & .76 & .74 & .91 & .90 \\
\hline
\end{tabular}

\section{Table 3 - Structural Model Fitness}

\begin{tabular}{|c|c|c|c|c|c|c|c|c|c|c|c|}
\hline & $\mathbf{X} 2$ & $\mathbf{X}$ /df & GFI & AGFI & PGFI & RMR & NFI & IFI & TLI & CFI & RMSEA \\
\hline $\mathbf{C}$ & 958.66 & 2.556 & .859 & .825 & .693 & .041 & .903 & .939 & .928 & .938 & 0.062 \\
\hline $\mathbf{K}$ & 877.905 & 2.341 & .869 & .838 & .701 & .059 & .843 & .903 & .887 & .902 & 0.059 \\
\hline
\end{tabular}




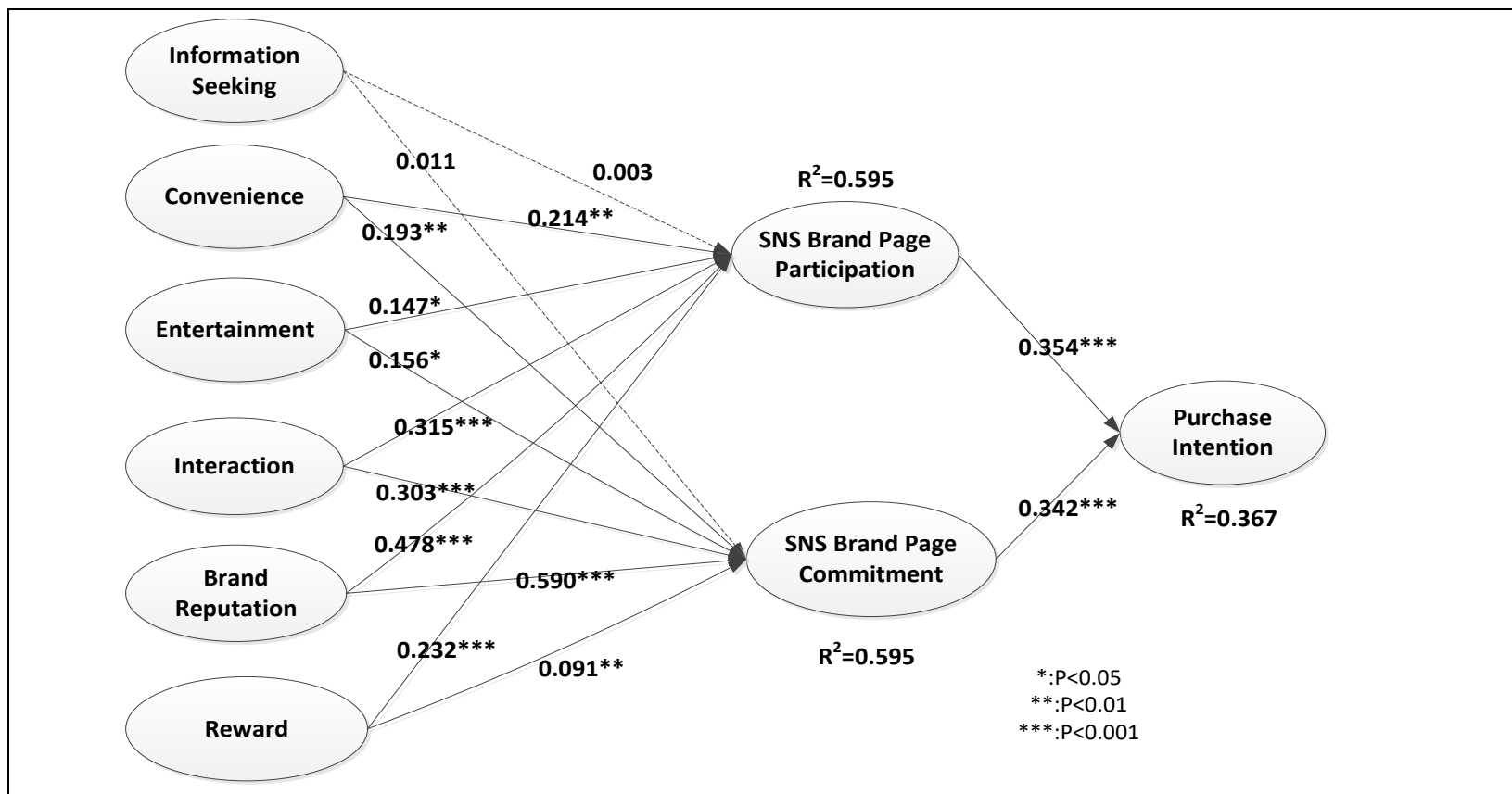

Figure 2 - Path Coefficients and $\mathbf{R}^{2}$ for Chinese Sample

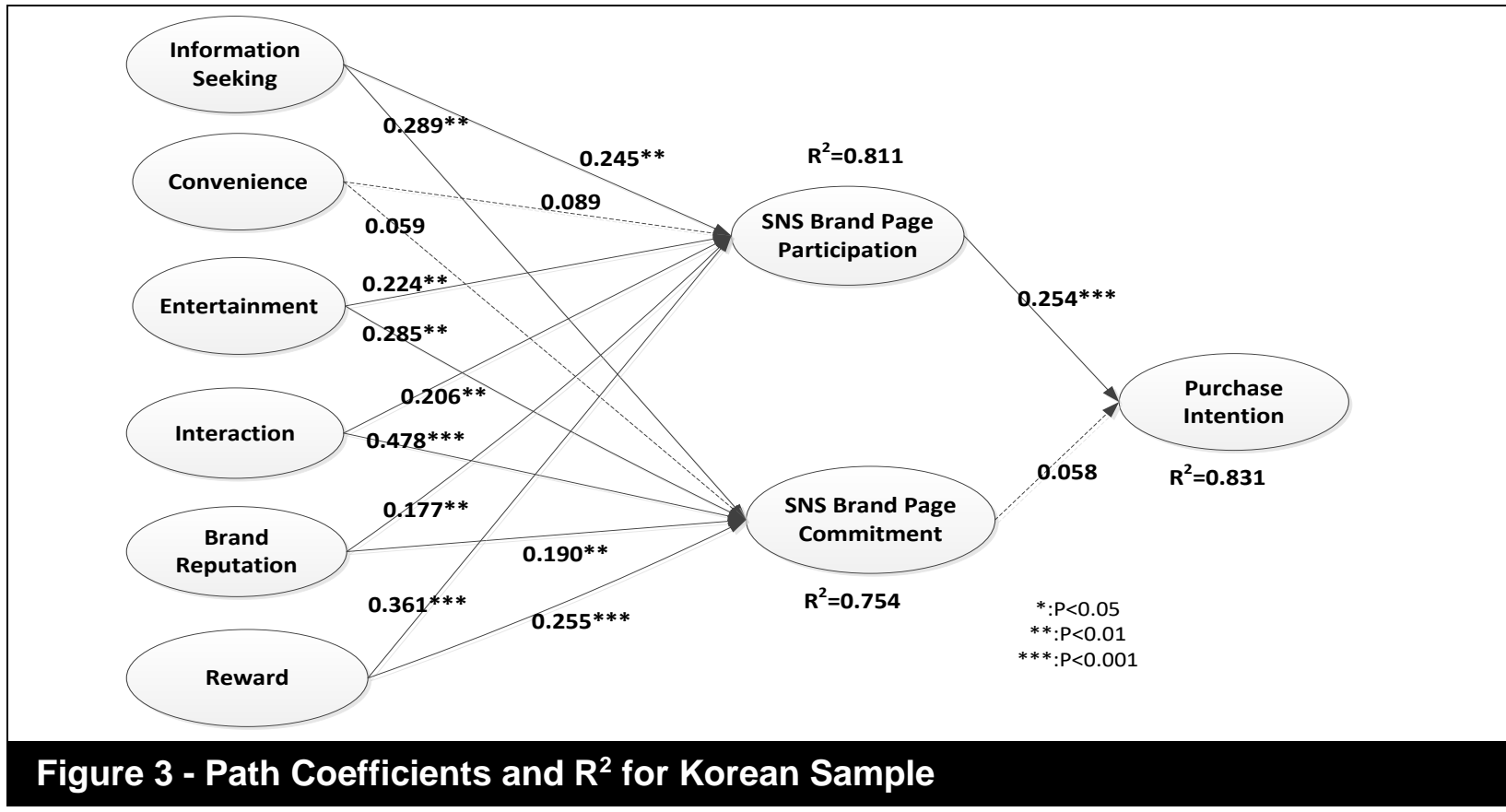

\section{Results and Discussion}

By focusing on SNS brand pages, this study tested the motivators-participation/ commitment-purchase intention relationship identified in the existing literature on traditional online brand communities
(Bagozzi and Dholakia, 2002; Bock et al., 2005; Borle et al., 2012; Gupta and Kim, 2007). In addition, this study collected data from two countries (i.e., China and Korea) to understand potential cultural differences. Our findings suggest that motivators identified in the current literature on 
traditional online brand communities largely hold in the context of SNS brand page. Most motivators (e.g., entertainment, reward, brand reputation, and interaction) were found to have a positive relationship with users' participation and commitment in SNS brand page in both China and Korea, consequently leading to purchase intention. However, the significance and the importance of these motivators differ between Chinese and Korean SNS brand page users.

First, non-significant motivators were found to be different between China and Korea. For Chinese SNS brand page users, information seeking was not positively associated with participation/commitment; for Korean users, convenience was not positively associated with participation/ commitment. These findings can be explained by the free Internet access in Korea and the Internet census in China. In Korea, virtual identity on SNS brand pages must be officially verified and Korean users may freely access information and brand news from various SNS such as Facebook and twitter. The safe and free Internet environment makes it easier for Korean users to participate in or commit to SNS brand pages. In China, however, important and sensitive information about brands are owned and controlled by a few highly involved brand professionals and may not be easily accessible by most SNS brand page users. Therefore, information seeking is non-significant for Chinese users' participation/commitment. The nonsignificant influence of information seeking might also be related to the low uncertainty avoidance of the Chinese culture which is less motivated to engage in information searching behaviors to reduce risks associated with purchase (e.g., Dawar et al., 1996; Money, 2000; Money and Crotts, 2003; Quintal, Lee, and Soutar, 2010; Solomon, 1999).

Second, the most influential motivator for participation/ commitment was also different between the two countries. The most influential factor was brand reputation in
China and reward in Korea. The strong impact of brand reputation in China may also be associated with its Internet environment. Due to a lack of free access to diverse and rich brand information in China, brand reputation appeared to be an importance reference to SNS brand page users. Further, the masculine culture of China may contribute to the dominant influence of brand reputation as research suggests that individuals from achievement/ success-oriented masculine culture places greater emphasis on brand reputation (e.g., De Mooij and Hofstede, 2002; De Mooij, 2010).

The strong influence of reward in Korea is consistent with prior studies (Sung et al., 2010, Treadaway and Smith, 2012; Yen et al., 2011) which found that Korean users took part in SNS brand pages mostly because of gift certificates, special promotions and coupons. This kind of participation by Korean users strengthened the connection between individuals and the brands. However, such dominant influence of reward in Korea is, to some extent, contradicting with Hofstede's arguments and related research (e.g., Hofstede, 2001; Kwok and Uncles, 2005; Newburry and Yakova, 2006). On the one hand, the strong influence of reward is consistent with the high uncertainty avoidance of the Korean culture as rewards received from SNS, which involves minimal risks and are more certain, are more appealing to high uncertainty avoidance cultures; on the other hand, the strong influence of reward is inconsistent with the feminine culture of Korea as the literature indicates that rewards are more appealing to masculine cultures.

Third, interaction played a prominent role in affecting commitment in both countries. The influence of interaction is related to the unique features of SNS brand page. Being a profile on a social networking website, SNS brand pages are embedded in an organically grown network of social ties, and have far more posts, feedbacks, and reviews than "product information sharing" 
communities (Jang et al., 2008; Nambisan and Baron, 2009). As a result, discussions among tightly connected users may cover a wider range of topics, ranging from brands (and products/services) to user experience and relevant personal stories. Therefore, SNS brand page users can gain great benefits through interactions, which consequently makes them more committed. The prominent role of interaction in China and Korea may also be related to the collectivist culture of the two countries. For example, marketing research on corporate websites found that collectivist cultures place greater emphasis on interactions between website users than individualist cultures do (e.g., Cho and Cheon, 2005a, 2005b; Pan and Xu, 2009).

Forth, SNS brand page participation and commitment were found to mediate the relationship between motivators and purchase intention in China, whereas in Korea only participation was found to mediate. This suggests that for Korean users, their SNS brand page commitment, which is driven by potential benefits obtained from SNS brand pages (e.g., interaction, reward), does not imply that Korean users are actually committed to the brand (or its product/service) and is not a good indicator of purchase intention.

Finally, the R-squares of purchase intention of the two samples suggest different explanatory power. In the Chinese sample, $36.7 \%$ of the variance in purchase intention could be explained by SNS brand page participation and commitment, while in the Korean sample, $83.1 \%$ of the variance could be explained by SNS brand page participation. The Internet environment might contribute to the differences. In Korea which has free and open Internet access, individuals are used to look up information on the Internet before making purchase decisions. As a result, their participation in SNS brand pages are more likely to affect purchase; in China, individuals may participate in or commit to SNS brand pages because of various benefits (i.e., interaction) they could potentially obtain, yet their participation and commitment do not necessarily have profound influence on purchase decisions due to the highly limited and controlled information in a censused Internet environment and there are other factors affecting their purchase decisions (e.g., Gao et al., 2015).

\section{Theoretical implications}

The research has two theoretical implications. First, findings of this study suggest that our current understandings about traditional online brand community might well apply in the relatively less examined context of SNS brand page. Despite the two major differences (i.e., userdriven vs. company-driven, and based on brand-likeness or not) between SNS brand pages and traditional online brand communities, this study found that most motivators affecting users' participation and commitment in traditional online brand communities still hold in SNS brand pages. Motivators like functional benefits, hedonic benefits, economic benefits, intrinsic benefits and brand reputation are important for having active and committed user groups in both SNS brand pages and online brand communities. Hence, existing understandings related to those motivators in the online brand community literature (e.g., design features providing great interaction among users) could be applied to SNS brand pages.

Second and more importantly, the investigation of potential cultural differences between China and Korea provides new insights regarding understanding crosscultural issues in the context of SNS brand page (or potentially in the context of traditional online brand community) and suggest directions for future studies. Although most of the motivators examined in existing online brand community research still holds in the context of SNS brand page, the importance of those motivators varies between the two countries. 
Our findings suggest that, first of all, Hofstede's culture framework is helpful for understanding cross-cultural differences in the context of SNS brand page, e.g., the importance of interaction in both China and Korea, the dominant influence of brand reputation in China. Also, our findings suggest that different culture dimensions may sometimes impose contrasting impacts, e.g., the dominant influence of reward in Korea is consistent with its high uncertainty avoidance culture but inconsistent with its feminine culture. The relative impact of different culture dimensions (e.g., how one culture dimension overrides or cancels out the influence of another dimension) needs further attention. Moreover, our findings suggest that external forces (e.g., the Internet environment in one country) may override the influence of cultureinformation seeking, a motivator generally important for masculine cultures like China, was found to be non-significant for Chinese SNS brand page users due to the Internet census in China. Finally, even though this study focuses on just two cultures, our discussion about cultural differences along Hofstede's culture dimensions (i.e., uncertainty avoidance and masculinity) allows our findings to apply to other cultures that score similarly with China/Korea on the two dimensions.

In summary, Hofstede's culture framework is found to be helpful for understanding cross-cultural issues in the context of SNS brand page and may be further exploited in related research (whether it is between China and Korea or not) in the future. However, its helpfulness might be discounted in certain countries with external forces (e.g., government regulation) imposing strong influence or constraint on individuals' attitudes and behaviors.

\section{Practical Implications}

Results of this study provide some practical implications. First of all, since SNS brand page is a good way to manage customer- brand relationship, brand managers or marketers should build more sustainable and vigorous SNS brand pages and craft SNS brand page strategies to fully take advantage of motivators that may increase participation and commitment (and hopefully purchase intention). The significant influences of certain motivators found in this study provide directions for SNS brand pages regarding what kinds of benefits need to be made explicit and easily spotted for users when they visit SNS brand pageThis will create opportunities to convert lurkers into active users. Interesting, entertaining or innovative information, sweepstakes, online events, and rewards are some of the approaches SNS brand pages can use. In addition, companies should also improve the design of their SNS brand pages to support interaction. For example, classifications of forums by topics can attract users to join discussions of their interest while making friends. Another example could be the group chat, which can create an interesting and friendly community atmosphere for users to interact. More peripheral functions such as easy navigation and topic ranking can also be considered. SNS brand pages should be closely monitored by companies so that questions and problems could be attended to in a timely (or even proactive) manner to alleviate potential negative impacts (Jahn and Kunz, 2012). Finally, more comprehensive scales (e.g., usage frequency, log-in time) to measure users' activities can also be developed to understand participation and commitment.

Second, global companies need to realize that SNS brand page users from different countries may have different attitudes and behaviors towards SNS brand pages. Therefore, global companies need to use different strategies to target SNS brand page users from different countries. For example, promoting brand reputation may encourage participation and commitment among Chinese users, while monetary rewards (e.g., coupons) are more effective to attract Korean users. 


\section{Limitations and Future Research Directions}

This study is not without limitations. One limitation is the sample and the generalizability of findings. Data was collected in only two countries, and most respondents aged between 20 and 40 (i.e., $88.2 \%$ in China, and $86.7 \%$ in Korea). Hence, findings may not apply to SNS brand page users in other countries or in other age groups. Another limitation is related to the different SNS platforms used in the two countries. For example, Facebook, which is widely used in many countries around the world, is not easily accessed in China. An equivalent of Facebook used by the Chinese sample is Wechat. Facebook and Wechat are both dominant (e.g., the number of Wechat users reached nearly 900 million- approximately 70 percent of the mobile phone users -by the third quarter of 2017, e.g., Tencent, 2017) and provide similar SNS brand page services. Although we do not believe that the different platforms may affect research validity, future research may compare the relationship among users of identical platforms.

Several future research directions exist. Related to our sample limitation, future research could try to verify the findings in other countries to increase generalizability of findings. Another future research direction could be to test moderating impacts of demographics (e.g., age group, gender) to identify potential differences among segmented SNS brand page users. Moreover, research suggests that participation and commitment are interconnected (Kang et al., 2014). Hence, future research may also investigate the potential relationship between participation and commitment and how they together influence purchase intention.

\section{Conclusion}

This study investigated motivators influencing individuals' participation and commitment in SNS brand pages as well as the potential impacts on purchase intentions in China and Korea. Results of the study provide empirical evidence regarding the motivators for and consequences of users' participation and commitment in the context of SNS brand page as well as potential cultural differences. Practical implications are provided for global companies to develop effective SNS brand page strategies for different countries.

\section{Acknowledgement}

This research was supported by the National Natural Science Foundation of China (Grant No. 71362027,71361007) and Natural Science Foundation of Hainan Province (Grant No. 20167254).

\section{Prior Publication}

Early versions of this research were presented at 2016 International Conference on Electronic Business and 2017 Americas Conference on Information Systems.

\section{References}

Ahn, H., Kwon, M. and Sung, Y. (2010). "Online Brand Communities Across Cultures: A Comparison between the US and Korea," International Journal of e-Business Management, 4(1), pp. 34-52.

Albers-Miller, N. and Gelb, B. (1996). "Business Advertising Appeals as a Mirror of Cultural Dimensions: A Study of Eleven Countries," Journal of Advertising, 25(4), pp. 57-70. 
Armstrong, A. G. and Hagel, J. (1995). "Real Profits from Virtual Communities," McKinsey Quarterly, 3, pp. 128141.

Bagozzi, R. P. and Dholakia, U. M. (2002). "Intentional Social Action in Virtual Communities," Journal of Interactive Marketing, 16(2), pp. 2-21.

Bagozzi, R. P. and Yi, Y. (1988). "On the Evaluation of Structural Equation Models," Journal of the Academy of Marketing Science, 16(1), pp. 74-94.

Beatty, S. E. and Kahle, L. R. (1988). "Alternative Hierarchies of the Attitude-Behavior Relationship: The Impact of Brand Commitment and Habit," Journal of the Academy of Marketing Science, 16(2), pp. 1-10.

Bock, G. W., Zmud, R. W., Kim, Y. G. and Lee, J. N. (2005). "Behavioral Intention Formation in Knowledge Sharing: Examining the Roles of Extrinsic Motivators, SocialPsychological Forces, and Organizational Climate," MIS Quarterly, 29(1), pp. 87-111.

Borle, S., Dholakia, U., Singh, S. and Durham, E. (2012). "An Empirical Investigation of the Impact of Facebook Brand Page Participation on Customer Behavior," Marketing Science, pp. 1-36.

Boyd, D. M. and Ellison, N. B. (2007). "Social Network Sites: Definition, History, and Scholarship," Journal of Computer-Mediated Communication, 13(1), pp. 210-230.

Butler, J. K. and Cantrell, R. S. (1994). "Communication Factors and Trust," Psychological Reports, 74(1), pp. 3334.

Cho, C. and Cheon, H. (2005a) "CrossCultural Comparisons of Interactivity On Corporate Web Sites: The United States, the United Kingdom, Japan, and South Korea," Journal of Advertising, 34(2), pp. 99-115.
Cho, C. and Cheon, H. (2005b) "Interactivity on Japanese versus American Corporate Websites," Journal of International Consumer Marketing, 17(4), pp. 41-63.

Coulter, K. S. (1998). "The Effects of Affective Responses to Media Context on Advertising Evaluations," Journal of Advertising, 27(4), pp. 41-51.

Dawar, N., Parker, P. M. and Price, L. J. (1996). "A cross-cultural study of interpersonal information exchange," Journal of International Business Studies, 27(3), pp. 497-516.

Day, E., and Stafford, M. R. (1997). "Agerelated Cues in Retail Services Advertising: Their effects on Younger Consumers," Journal of Retailing, 73(2), pp. 211-233.

Delgado-Ballester, E., Munuera-Alemán, J. L. and Yagüe-Guillén, M. J. (2003). "Development and Validation of a Brand Trust Scale," International Journal of Market Research, 45(1), pp. 35-53.

De Mooij, M. and Hofstede, G. (2002) "Convergence and divergence in consumer behavior: implications for international retailing." Journal of Retailing, 78, pp. 61-69.

De Mooij, M. (2004). "Consumer Behavior and Culture: Consequences for Global Marketing and Advertising," Thousand Oaks, 159, pp. 129-139.

De Mooij, M. (2010). Global Marketing and Advertising: Understanding Cultural Paradoxes (3rd ed.). Sage Publications: Asia-Pacific, Singapore.

Dholakia, U. M., Bagozzi, R. P. and Pearo, L. K. (2004). "A Social Influence Model of Individual Participation in Network and Small Group Based Virtual Communities," Journal of Research in Marketing, 21(3), pp. 241-263. 
Dodds, W. B., Monroe, K. B. and Grewal, D. (1991). "The Effects of Price, Brand and Store Information on Buyers' Product Evaluations," Journal of Marketing Research, 28(8), pp. 307319.

Ducoffe, R. H. (1996). "Advertising Value and Advertising on the Web," Journal of Advertising Research, 36, pp. 21-34.

Escalas, J. E. and Stern, B. B. (2003). "Sympathy and Empathy: Emotional Responses to Advertising Dramas," Journal of Consumer Research, 29(4), pp. 566-578.

Fan, Q. J., Lee, J. Y. and Kim, J. I. (2013). "The Impact of Web Site Quality on Flow-Related Online Shopping Behaviors in C2C E-market Places," Managing Service Quality, 23(5), pp. 364-387.

Flanagin, A. (2005). "IM Online: Instant Messaging Use among College Students," Communication Research, 22(3), pp. 175-187.

Flavián, C. and Guinalíu, M. (2006). "Individual Trust, Perceived Security and Privacy Policy: Three Basic Elements of Loyalty to a Web Site," Industrial Management \& Data Systems, 106(5), pp. 601-620.

Fornell, C. and Larcker, D. F. (1981). "Evaluating Structural Equation Models with Unobservable Variables and Measurement Error," Journal of Marketing Research, 18(1), pp. 39-50.

Gao, L, Waechter, K. A., and Bai, X. (2015). 'Understanding consumers' continuance intention towards mobile purchase: A theoretical framework and empirical study-A case of China", Computers in Human Behavior, 53, pp. 249-262.

Garbarino, E. and Johnson, M. S. (1999). "The Different Roles of Satisfaction, Trust, and Commitment in Customer Relationships," Journal of Marketing, 63(2), pp. 70-87.
Guo, Z., Tan, F. B. and Cheung, K. (2010). "Students' uses and gratifications for using computer-mediated communication media in learning contexts," Communications of the Association for Information Systems, 27(1), pp. 339378.

Gupta, S. and Kim, H. W. (2007). "Developing the Commitment to Virtual Communities: The Balanced Effects of Cognition and Affect," The Journal of Information Resources Management, 20(1), pp. 28-45.

Ha, H. and Perks, H. (2005). "Effect of Individual Perceptions of Brand Experience on the Web: Brand Familiarity, Satisfaction, and Brand Trust," Journal of Individual Behavior, 4(6), pp. 438-452.

Hagit, M. and Efrat, P. (2017). "Why Do Academics Use Academic Social Networking Sites?" International Review of Research in Open \& Distributed Learning, 18(1), pp. 1-22.

Han, K. S. (2016). "Study of Structural Relationship between the Value Proposition of Facebook Brand Fan Pages and Commitment and Engagement," Indian Journal of Science \& Technology, 9(41), pp.1-5.

Heckhausen, J. and Heckhausen, H. (2008). Motivation and Action. (2nd ed.) Sage Publications: Cambridge University Press, New York, NY.

Henten, A., Olesen, H., Saugstup, D., and Tan, S. (2003). "New Mobile Systems and Services in Europe, Japan and South Korea," The Stockholm Mobility Roundtable, Centre for Tele Information, Lyngby, Demark.

Hofstede, G. (1983). "Dimensions of National Cultures in Fifty Countries and Three Regions," Immunlogy \& Cell Biology, 90(4), pp. 429-440. 
Hofstede, G. (2001). Culture's Consequences: Comparing Values, Behaviors, Institutions, and Organizations across Nations. (2nd ed.) Sage publications: Thousand Oaks, CA.

Jackson, L. A. and Wang, J. L. (2013). "Cultural Differences in Social Networking Site Use: a Comparative Study of China and the United States," Computers in Human Behavior, 29(3), pp. 910-921.

Jahn, B. and Kunz, W. (2012). "How to Transform Individuals into Fans of your Brand," Journal of Service Management, 23(3), pp. 344-361.

Jang, H., Olfman, L., Ko, I., Koh, J. and Kim, K. (2008). "The Influence of On-line Brand Community Characteristics on Community Commitment and Brand Loyalty", Inter-national Journal of Electronic Commerce, 12(3), pp. 5780.

Jin, B., Park, J. Y. and Kim, H. S. (2010). "What Makes Online Communities Members Commit? A social Exchange Perspective," Behaviour \& Information Technology, 29(6), pp. 587-599.

Kang, J., Tang, L. and Fiore, A. M. (2014). "Enhancing Consumer-Brand Relationships on Restaurant Facebook Fan Pages: Maximizing Consumer Benefits and Increasing Active Participation," International Journal of Hospitality Management, 36(1), pp. 145-155.

Kassim, N. and Abdullah, N. A. (2010). "The Effect of Perceived Service Quality Dimensions on Customer Satisfaction, Trust, and Loyalty in E-commerce Settings: a Cross Cultural Analysis," Asia Pacific Journal of Marketing and Logistics, 22(3), pp. 351-371.

Katz, E. Gurevitch, M. and Haas, H. (1973). "On the Use of Mass Media for Important Things," American Sociological Review, 38(2), pp. 164181.
Kelley, S. W., Donnelly Jr, J. H. and Skinner, S. J. (1990). "Customer Participation in Service Production and Delivery," Journal of Retailing, 66(3), pp. 315335.

Kim, H. T. (2016). "Comparing the Economic Developments Between South Korea and China," A with Honors Projects. http://spark.parkland. edu/ah/166.

Kim, Y., Sohn, D. and Choi, S. M. (2011). "Cultural Difference in Motivations for Using Social Network Sites: a Comparative Study of American and Korean College Students," Computers in Human Behavior, 27(1), pp. 365372.

Kippax, S. and Murray, J. P. (1980). "Using the Mass Media: Need Gratification and Perceived Utility," Communication Research, 7(3), pp. 335-360.

Ko, H., Cho, C. H. and Roberts, M. S. (2005). "Internet Uses and Gratifications," Journal of Advertising, 34(2), pp. 57-70.

Korgaonkar, P. K. and Wolin, L. D. (1999). "A Multivariate Analysis of Web Usage," Journal of Advertising Research, 39(2), pp. 53-68.

Kujur, F. and Singh, S. (2017). "Engaging Customers Through Online Participation in Social Networking Sites," Asia Pacific Management Review, 22(1), pp. 16-24.

$\mathrm{Ku}$, Y. C., Chu, T. H. and Tseng, C. H. (2013). "Gratifications for Using CMC Technologies: A Comparison among SNS, IM, and E-mail," Computers in Human Behavior, 29, pp. 226-234.

Kwok, S. and Uncles, M. (2005). "Sales promotion effectiveness: the impact of consumer differences at an ethnic group level", Journal of Product \& Brand Management, 14(3), pp. 170186 
Lee, C. S. and Ma, L. (2012). "News Sharing in Social Media: The Effect of Gratifications and Prior Experience," Computers in Human Behavior, 28(2), pp. 331-339.

Lee, Y., Ahn, W. and Kim, K. (2008). "A Study on the Moderating Role of Alternative Attractiveness in the Relationship between Relational Benefits and Individual Loyalty," International Journal of Hospitality \& Tourism Administration, 9(1), pp. 52 70.

Lee, Y., Kim, J., Lee, I., and Kim, H. (2002). "A Cross-cultural Study on the Value Structure of Mobile Internet Usage: Comparison between Korea and Japan," Journal of Electronic Commerce Research, 3(4), pp. 227-239.

Leung, L. (2001). "College Student Motives for Chatting on ICQ," New Media \& Society, 3(4), pp. 483-500.

Li, D., Browne, G. J. and Wetherbe, J. C. (2006). "Why do Internet Users Stick with a Specific Web Site? A Relationship Perspective," International Journal of Electronic Commerce, 10(4), pp. 105-141.

Lin, K. Y. and Lu, H. P. (2011). "Why People Use Social Networking Sites: An Empirical Study Integrating Network Externalities and Motivation Theory," Computers in Human Behaviors, 27(3), pp. 1152-1161.

Mahrous, A. A. and Abdelmaaboud A. K. (2017). "Antecedents of Participation in Online Brand Communities and Their Purchasing Behavior Consequences." Service Business, 11(2), pp. 229-251.

Mckinney, L. N. (2004). "Creating a Satisfying Internet Shopping Experience Via Atmospheric Variables," International Journal of Consumer Studies, 28(3), pp. 268-283.
Men, L. R. and Tsai, W. H. S. (2012). "How companies cultivate relationships with publics on social network sites: evidence from china and the united states," Public Relations Review, 38(5), pp. 723-730.

Mengze, S. H. I. and Andrea, C. W. (2014). "Money Talks to Online Opinion Leaders What Motivates Opinion Leaders to Make Social Network Referrals," Journal of Advertising Research, 54(1), pp. 81-91.

Milner, L., Fodness, D. and Speece, M. W. (1993). "Hofstede's research on crosscultural work-related values: implications for consumer behavior," European Advances in Consumer Research, 1, pp. 70-76

Money, R. B. and Crotts, J. C. (2003) "The effect of uncertainty avoidance on information search, planning, and purchases of international travel vacations," Tourism Management, 24(2), pp. 191-202.

Money, R. B. (2000). Social networks and referrals in international organizational buying of travel services. International Journal of Hospitality and Tourism Administration, 1(1), pp. 27-48.

Moon, J. W. and Kim, Y. (2001). "Extending the TAM for a World-Wide-Web Context," Information \& Management, 38, pp. 217-230.

Moorman, C., Zaltman, G. and Deshpande, R. (1992), "Relationships between Providers and Users of Market Research: The Dynamics of Trust Within and between Organizations," Journal of Marketing Research, 24, pp. 314-328.

Morgan, R. M. and Hunt, S. D. (1994). "The Commitment Trust Theory of Relationship Marketing," Journal of Marketing, 58(3), pp. 20-38. 
Muniz, A. M. and O' Guinn, T. C. (2001). "Brand Communities," Journal of Individual Research, 27(4), pp. 412432.

Muntinga, D. G., Moorman, M. and Smit, E. G. (2011). "Introducing COBRAs: Exploring Motivations for BrandRelated Social Media Use," International Journal of Advertising, 30(1), pp. 13-46.

Nambisan, S. and Baron, R. A. (2009). "Different Roles, Different Strokes: Organizing Virtual Customer Environments to Promote Two Types of Customer Contributions," Organization Science, 21(2), pp. 554-572.

Newburry, W. and Yakova, N. (2006). "Standardization preferences: A function of national culture, work interdependence and local embeddedness," Journal of International Business Studies, 37, pp. 44-60.

Pan, P. L. and Xu, J. (2009). "Online strategic communication: A crosscultural analysis of U.S. and Chinese corporate websites," Public Relations Review, 35(3), pp. 251-253.

Podsakoff, P. M., MacKenzie, S. B., Lee, J. Y. and Podsakoff, N. P. (2003). "Common Method Biases in Behavioral Research: Acritical Review of the Literature and Recommended Remedies," Journal of Applied Psychology, 88(5), pp. 879-903.

Quintal, V. A., Lee, J. A. and Soutar, G. N. (2010). "Tourists' information search: the differential impact of risk and uncertainty avoidance," International Journal of Tourism Research, 12(4), pp. 321-333.

Raacke, J. and Bonds-Raacke, J. B. (2008). "MySpace and Facebook: Applying the Uses and Gratifications Theory to Exploring Friend-Networking Sites," Cyberpsychol Behavior, 11(2), pp. 169-174.
Raju, S., Unnava, H. R. and Montgomery, N. V. (2009). "The Effect of Brand Commitment on the Evaluation of Nonpreferred Brands: A Disconfirmation Process," Journal of Individual Research, 35, pp. 851-863.

Rohm, A. J. and Swaminathan, V. (2004). "a Typology of Online Shoppers Based on Shopping Motivations," Journal of Business Research, 57(7), pp. 748757.

Rosenthal, B. and Brito, E. P. Z. (2017). "How Virtual Brand Community Traces May Increase Fan Engagement in Brand Pages," Business Horizons, 60 (3), pp. 375-384.

Rubin, A. M. (1993). "Audience Activity and Media Use," Communications Monographs, 60(1), pp. 98-103.

Ruiz-Mafe, C., Marti-Parreno, J. and SanzBlas, S. (2014). "Key Drivers of Individual Loyalty to Facebook Fan Pages," Online Information Review, 38(3), pp. 362-380.

Sangwan, S. (2005). "Virtual Community Success: A Uses and Gratifications Perspective," Proceedings of the 38th Annual Hawaii International Conference on System Sciences, Big Island, Hawaii.

Severin, K., Lee, D. H., Kennan, A. J. and Ghadiri, M. R. (1997). "A Synthetic Peptide Ligase," Nature, 389(16), pp. 706-709.

Sheldon, P. (2008). "The Relationship between Unwillingness-to-Communicate and Students' Facebook use," Journal of Media Psychology, 20(2), pp. 67-75.

Sheldon, P., Rauschnabel, P. A., Antony, M. G. and Scar, C. (2017). "A crosscultural comparison of Croatian and American social network sites: Exploring cultural differences in motives for Instagram use," Computers in Human Behavior, 75, pp. 643-651. 
Simply Measured. (2017). "Top and Brand Social Media Marketing Report in 2016," Retrieved from http://www. 199it.com/archives/498107.html/ on August 14, 2017.

SINA, CIC., (2013). "Enterprise Microblogging White Paper 2012," Retrieved from http: //www.slideshare.net/ClC China/2012-cic/ on September 20, 2013.

Soares, A. M., Farhangmehr, M. and Shoham, A. (2007). "Hofstede's Dimensions of Culture in International Marketing Studies," Journal of Business Research, 60(3), pp. 277284.

Solomon, M. R. (1999). Consumer behavior (4th ed.). Sage Publications: Upper Saddle River, NJ: Prentice-Hall.

Sondergaard, M. (1994). "Research Note: Hofstede's Consequences: A Study of Reviews, Citations and Replications," Organization Studies, 15(3), pp. 447456.

Steenkamp, J. (2001). "The Role of National Culture in International Marketing Research," International Marketing Review, 18(1), pp. 30-44.

Sung, Y. J., Kim, Y. J., Kwon, O. Y. and Moon, J. H. (2010). "An Explorative Study of Korean Individual Participation in Virtual Brand Communities in Social Network Sites," Journal of Global Marketing, 23(5), pp. 430-445.

Tencent. (2017). "2017 First Quarter and Annual Results Announcement" Received from https://finance.yahoo. com/news/tencent-announces-2017first-quarter-114600631.html/ on August 3, 2017.

Treadaway, C. and Smith, M. (2012). Facebook and Marketing: An Hour a Day. John Wiley \& Sons.
Tse, D. K., Belk, R. W. and Zhou, N. (1989). "Becoming a Individual Society: a Longitudinal and Cross-Cultural Content Analysis of Print Ads from Hong Kong, the People's Republic of China, and Taiwan," Journal of Individual Research, 15(4), pp. 457-72.

Turow, J. (2010). "The Hyperlinked Society: Questioning Connections in the Digital Age," Playing Doctor, University of Michigan Press.

UI Haq, Z. (2012). "Attitude Toward SMS Advertising: A Survey with Reference to Indian Individuals," Journal Internet Commerce, 11(4), pp. 271-290.

Van Doorn, J., Lemon, K. N., Mittal, V., Nass, S., Pick, D., Pirner, P. and Verhoef, P. (2010). "Customer Engagement Behavior: Theoretical Foundations and Research Directions," Journal of Service Research, 13(3), pp. 253-266.

Vasalou, A., Joinson, A. N. and Courvoisier, D. (2010). "Cultural Differences, Experience with Social Networks and the Nature of 'True Commitment' in Facebook," International Journal of Human-Computer Studies, 68(10), pp. 719-728.

Venkatesh, V. and Brown, S. A. (2001). "A longitudinal investigation of personal computers in Homes: Adoption determinants and emerging challenges." MIS Quarterly, 25(1), pp. 71. 102.

Vidya, N. A., Fanany, M. L. and Budi, I. (2015). "Twitter Sentiment to Analyze Net Brand Reputation of Mobile Phone Providers," Procedia Computer Science, 72, pp. 519-526.

Vriesa, L., Genslera, S. and Leeflang, P. S. H. (2012). "Popularity of Brand Posts on Brand Fan Pages: An Investigation of the Effects of Social Media Marketing," Journal of Interactive Marketing, 26, pp. 83-91. 
Factors Motivating Customers' SNS Brand Page Behaviors / Song et al.

Vivek, S. D. (2009). A Scale of Consumer Engagement, Doctor of Philosophy Dissertation, Department of Management and Marketing. Sage Publication: The University of Alabama.

Wang, T. L. (2014). "The Usage Behaviors, Motivations and Gratifications of Using User-Generated Media: The Case Study of Taiwan's YouTube," Advances in Journalism \& Communication, 2(4), pp. 137-150.

Yang, S., Choi, J. E. and Kim, H. W. (2016). "A Study on Factors Influencing the Customer," Proceedings of 61st The IIER International Conference, IIER.
Yen, H. R., Hsu, S. H. Y. and Huang, C. Y. (2011). "Good Soldiers on the Web: Understanding the Drivers of Participation in Online Communities of Consumption," International Journal of Electronic Commerce, 15(4), pp. 89120.

Zaichkowsky, J. L. (1985). "Measuring the involvement construct," Journal of Individual Research, 12(3), pp. 341352.

Zeithaml, V. A., Berry, L. L. and Parasuraman, A. (1996). "The Behavioral Consequences of Service Quality," Journal of Marketing, 60(4), pp. 31-46. 


\section{Appendix}

\begin{tabular}{|c|c|c|}
\hline Construct & Measurement Scales & References \\
\hline $\begin{array}{l}\text { Information } \\
\text { seeking }\end{array}$ & $\begin{array}{l}\text { The information of the SNS brand page is valuable for me. } \\
\text { The information of the SNS brand page is up-to-date for me. } \\
\text { The information of the SNS brand page is exact for me. } \\
\text { I think this SNS brand page is a valuable information resource. }\end{array}$ & $\begin{array}{l}\text { Ducoffe,1996; } \\
\text { Korgaonkar and } \\
\text { Wolin,1999; Ku et al., } \\
\text { 2013; Turow, } 2010\end{array}$ \\
\hline Convenience & $\begin{array}{l}\text { I can get any information very easy from this SNS brand page. } \\
\text { I can use this SNS brand page without any limitation in time and place. } \\
\text { The SNS brand page is very convenient to use. }\end{array}$ & $\begin{array}{l}\text { Mckinney, 2004; } \\
\text { Rohm and } \\
\text { Swaminathan, } 2004\end{array}$ \\
\hline Entertainment & $\begin{array}{l}\text { The content of the SNS brand page is fun. } \\
\text { The content of the SNS brand page is pleasant. } \\
\text { The content of the SNS brand page is entertaining. }\end{array}$ & Moon and Kim, 2001 \\
\hline Interaction & $\begin{array}{l}\text { I can get answers from the brand on this SNS brand page. } \\
\text { I can interact with others on this SNS brand page. } \\
\text { I can communicate with others on this SNS brand page. } \\
\text { I can give feedback to others on this SNS brand page. }\end{array}$ & $\begin{array}{l}\text { Nambisan and Baron, } \\
2009\end{array}$ \\
\hline $\begin{array}{l}\text { Brand } \\
\text { reputation }\end{array}$ & $\begin{array}{l}\text { In my opinion this brand is respected by people. } \\
\text { In my opinion this brand is positive. } \\
\text { I think favorably about this brand. }\end{array}$ & $\begin{array}{l}\text { Coulter, 1998; Day } \\
\text { and Stafford, 1997; } \\
\text { Escalas and Stern, } \\
2003\end{array}$ \\
\hline Reward & $\begin{array}{l}\text { I can get bonuses following this SNS brand page. } \\
\text { I can get reward following this SNS brand page. } \\
\text { I can get more points following this brand page. }\end{array}$ & Sung et al., 2010 \\
\hline Participation & $\begin{array}{l}\text { I frequently provide useful information to other members in general. } \\
\text { I do my best to participate in activities offered on the brand's SNS brand } \\
\text { page. } \\
\text { I post messages and responses on the SNS brand page with great } \\
\text { enthusiasm and high frequency. }\end{array}$ & Kelley et al., 1990 \\
\hline Commitment & $\begin{array}{l}\text { I feel I am part of a community around this SNS brand page. } \\
\text { I feel the good relationship with others in this SNS brand page. } \\
\text { I think is important for me to connect with others in this SNS brand page. } \\
\text { I am an active supporter of this SNS brand page. }\end{array}$ & Moorman et al., 1992 \\
\hline $\begin{array}{l}\text { Purchase } \\
\text { intention }\end{array}$ & $\begin{array}{l}\text { I intend to remain loyal to this brand in the future. } \\
\text { I will not stop buying this brand. } \\
\text { I will have the intention of continuing to buy this brand. }\end{array}$ & Zeithaml et al., 1996 \\
\hline
\end{tabular}




\begin{tabular}{|c|c|c|c|c|c|c|c|c|c|}
\hline \multirow{2}{*}{ Items } & \multicolumn{9}{|c|}{ Loading } \\
\hline & 1 & 2 & 3 & 4 & 5 & 6 & 7 & 8 & 9 \\
\hline Information seeking 1 & 0.852 & & & & & & & & \\
\hline Information seeking 2 & 0.874 & & & & & & & & \\
\hline Information seeking 3 & 0.769 & & & & & & & & \\
\hline Information seeking 4 & 0.806 & & & & & & & & \\
\hline Convenience 1 & & & & & & 0.502 & & & \\
\hline Convenience 2 & & & & & & 0.84 & & & \\
\hline Convenience 3 & & & & & & 0.773 & & & \\
\hline Entertainment 1 & & & & & 0.725 & & & & \\
\hline Entertainment 2 & & & & & 0.808 & & & & \\
\hline Entertainment 3 & & & & & 0.772 & & & & \\
\hline Interaction1 & & 0.698 & & & & & & & \\
\hline Interaction2 & & 0.71 & & & & & & & \\
\hline Interaction3 & & 0.834 & & & & & & & \\
\hline Interaction4 & & 0.825 & & & & & & & \\
\hline Brand reputation 1 & & & & 0.76 & & & & & \\
\hline Brand reputation 2 & & & & 0.781 & & & & & \\
\hline Brand reputation 3 & & & & 0.791 & & & & & \\
\hline Reward 1 & & & 0.864 & & & & & & \\
\hline Reward 2 & & & 0.89 & & & & & & \\
\hline Reward 3 & & & 0.875 & & & & & & \\
\hline Participation 2 & & & & & & & 0.765 & & \\
\hline Participation 3 & & & & & & & 0.802 & & \\
\hline Participation 4 & & & & & & & 0.84 & & \\
\hline Commitment 1 & & & & & & & & & 0.536 \\
\hline Commitment 2 & & & & & & & & & 0.731 \\
\hline Commitment 3 & & & & & & & & & 0.826 \\
\hline Commitment 4 & & & & & & & & & 0.48 \\
\hline Purchase intention 1 & & & & & & & & 0.838 & \\
\hline Purchase intention 2 & & & & & & & & 0.86 & \\
\hline Purchase intention 3 & & & & & & & & 0.881 & \\
\hline
\end{tabular}




\section{Appendix C - Exploratory Factor Analysis Results (Korean Sample)}

\begin{tabular}{|c|c|c|c|c|c|c|c|c|c|}
\hline \multirow{2}{*}{ Items } & \multicolumn{9}{|c|}{ Loading } \\
\hline & 1 & 2 & 3 & 4 & 5 & 6 & 7 & 8 & 9 \\
\hline Information seeking 1 & & 0.706 & & & & & & & \\
\hline Information seeking 2 & & 0.797 & & & & & & & \\
\hline Information seeking 3 & & 0.65 & & & & & & & \\
\hline Information seeking 4 & & 0.783 & & & & & & & \\
\hline Convenience 1 & & & & & & 0.625 & & & \\
\hline Convenience 2 & & & & & & 0.798 & & & \\
\hline Convenience 3 & & & & & & 0.785 & & & \\
\hline Entertainment 1 & & & & 0.786 & & & & & \\
\hline Entertainment 2 & & & & 0.811 & & & & & \\
\hline Entertainment 3 & & & & 0.73 & & & & & \\
\hline Interaction1 & 0.811 & & & & & & & & \\
\hline Interaction2 & 0.778 & & & & & & & & \\
\hline Interaction3 & 0.702 & & & & & & & & \\
\hline Interaction4 & 0.734 & & & & & & & & \\
\hline Brand reputation 1 & & & 0.793 & & & & & & \\
\hline Brand reputation 2 & & & 0.8 & & & & & & \\
\hline Brand reputation 3 & & & 0.789 & & & & & & \\
\hline Reward 1 & & & & & 0.76 & & & & \\
\hline Reward 2 & & & & & 0.872 & & & & \\
\hline Reward 3 & & & & & 0.859 & & & & \\
\hline Participation 2 & & & & & & & & & 0.804 \\
\hline Participation 3 & & & & & & & & & 0.823 \\
\hline Participation 4 & & & & & & & & & 0.682 \\
\hline Commitment 1 & & & & & & & 0.815 & & \\
\hline Commitment 2 & & & & & & & 0.846 & & \\
\hline Commitment 3 & & & & & & & 0.744 & & \\
\hline Commitment 4 & & & & & & & 0.767 & & \\
\hline Purchase intention 1 & & & & & & & & 0.887 & \\
\hline Purchase intention 2 & & & & & & & & 0.906 & \\
\hline Purchase intention 3 & & & & & & & & 0.917 & \\
\hline
\end{tabular}




\section{About the Authors}

Mengmeng Song is currently an associate professor of Marketing at the college of Tourism, in the Hainan University (HNU), China. Prior to joining HUN, she received her Ph.D. in Marketing from PaiChai University(Korea). Then, she served as assistant professor in 2015. Her main research areas are online consumer behavior (online participation) and brand marketing (susceptibility to global consumer culture). She has published her research findings in Journal of Korea Contents Association, Journal of Product Research, etc.

Nan (Tina) Wang is an Assistant Professor in Management Information Systems (MIS) at Eastern Illinois University. She received her PhD from the University of Oklahoma. Her research interests include innovation adoption and implementation, computermediated communication, affect and affective social processes, managerial cognition, organizational communication and knowledge management. Her research uses both quantitative and qualitative research methods, and has been presented at various conferences such as ICIS and AoM. She has also worked as associate editor and mini-track chair for conferences such as ICIS and AMCIS, and has served as a reviewer for journals such as MISQ and ISR.

Xianfeng Zhang is a professor of Information Systems and Electronic Commerce at the Hainan Normal University of Information Technologies, China. She served as associate professor. Prior to assistant professor, she did her Ph.D. in Economics from Xi'an Jiaotong University. She also conducted one-year visiting scholar research in both Georgia Institute of Technology and Texas Tech University. Her main research interests include online trusted third-parties (reputation systems, online seals programs and e-WOM), eservices (e-tourism, e-marketplaces), and online consumer behavior (online stickiness). She has published her research in Online Information Review, Electronic Commerce, etc.

Lin Qiao is a postgraduate student of Technology Economy and Management, in the School of Tourism, at Hainan University, China. Her research interest focuses on online consumer behavior (online participation). 